\title{
Evaluation of Different Types of Solar Garden Lamps
}

\author{
M. Roshita Devi ${ }^{1 *}$, Velivelli Vijaya Lakshmi ${ }^{2}$, D. Ratna Kumari ${ }^{3}$ and S.L. Kameswari $^{4}$ \\ ${ }^{1}$ Department of RMCS, College of Community Science, Professor Jayashankar Telangana \\ State Agricultural University, Hyderabad, India \\ ${ }^{2}$ Department of FRM, AICRP-H.Sc., Professor Jayashankar Telangana State Agricultural \\ University, Hyderabad, India \\ ${ }^{3}$ College of Community Science, Professor Jayashankar Telangana State Agricultural \\ University, Hyderabad, India \\ ${ }^{4}$ Department of HECM, College of Community Science, Professor Jayashankar Telangana \\ State Agricultural University, Hyderabad, India \\ *Corresponding author
}

\begin{tabular}{|l|}
\hline K ey w or d s \\
Solar garden lamp, \\
Battery, Solar \\
panel, LED
\end{tabular}

Solar energy is the most important and cleanest energy source that can be used in almost every field. Almost $25 \%$ of produced electricity is being consumed for lighting in all over the world. Therefore, using alternative energy for lighting systems has become inevitable. Usage of alternative energy for lighting in the local parks, gardens and streets, long distance highways and roads have become widespread quickly. In addition to the money savings, solar-powered Led lighting offers substantial environmental and health benefits. Technological developments have allowed the use of LEDs technology in many general illumination applications, from houses to commercial or outdoor spaces. Different varieties of solar garden lamps were found to be manufactured in many countries like China, USA and Middle East but in India most of the solar garden lamps available in the market were imported from China. So, people used to buy through online and offline source. An attempt was made to analyse the features of different types of solar garden lamps available in the market. Secondary sources of data were used to analyse the features of the lamps.

\section{Introduction}

Garden lighting is a mostly concerning critically in performing regular human activities during night time because of its strategic importance for economic and social stability. Inefficient lighting wastes significant financial resources each year, and poor 
lighting creates unsafe conditions. Energy efficient technologies and design can change garden lighting costs dramatically (often by 25-60\%); these savings can eliminate or reduce the need for new generating plants and provide the capital for alternative energy solutions for people.

Solar garden lights are small lamps based on LED, a rechargeable battery and a small solar panel for recharging battery during sunlight. It conserves energy in a maximum amount. Solar lighting systems are one of the easiest to be maintained. Unlike most rechargeable products, however, solar lights can be exposed to sunlight during the day in order to provide lighting at night. Sunlight that shines on the solar panels generates electricity that is then stored into the solar light batteries, and is discharged once it is dark outside. The batteries in solar lights last about two years and replacement of batteries can be done by purchasing and be installed within solar lights to avoid purchasing new lights. But it also has the drawbacks which needs to charge and work properly only during the sunny days.

Many people were not aware of the different solar garden lamps available in the market with reference to the features, design, functionality, advantages and disadvantages. According to the size and design, the price of the lamp also varied.

Vinutharani et al., (2016) conducted a study on sensor based smart lighting system and gave the idea for developing low cost, adaptable, easy to install, wireless sensor based smart lighting system that automatically adjust the intensity of light for energy saving and satisfied the user. The study illustrated a system that makes use of Pyroelectric InfraRed (PIR) sensor, $\mathrm{CO}_{2}$ sensor \& Light sensors (LDR). The dimming of light was achieved using PIR sensor. Intensity measurement and power consumption was measured by using Light sensors. A simple low cost multitasking hybrid solar emergency lamp has a motion detector with an additional feature of charging better by mains supply even though the weather is cloudy.

This is not only a simple solar emergency lamp having motion detector sensors which ensures the safety but also the system was designed using good materials at low cost. The components of the system provided better light in night and ensure the safety of nearby area. The whole system operates automatically. The system did not require any expert person to operate it (Prabhat et al., 2016).

Hence, to know about the different solar garden lamps available in the market, the present study has been taken up with the following objectives.

To study the features of different solar garden lamps available

To analyse the energy efficiency of each of the lamps

\section{Materials and Methods}

Secondary sources of information were used to assess the features of garden lamps available in the market. Random market survey was conducted in the main city of Hyderabad to know the varieties of lights available in the lighting shops. A total of 13 different garden lamps available in the markets of Hyderabad and Secunderabad were selected for evaluation.

Solar garden lamps included in the study were ScrossBright waterproof solar wireless security motion sensor LED night light for outdoor/garden wall (Black), Crocon new solar powered rechargeable LED garden light auto on/off waterproof, Enjocho solar light 
bulb, Quace solar garden light, Ozoy solar light, Ohuhu Stainless Steel Solar Garden Lights, Nekteck Solar Powered Garden Spotlight Set, URPOWER Wireless Solar Lights, SolarDuke Hanging Solar Light Lantern Gama Sonic Victorian Lamp Post Solar Light, Moonrays Payton solar LED plastic path light, SolarGlow stainless steel LED garden lights and Newhouse lighting solar flickering LED tiki torches.

The lamps used for the evaluation were bought from different market sources i.e. through online and offline.

The selected lamps were analyzed for features that were incorporated in the design and parameters evaluated for each lamp included lumens illuminated, charging time, working hours, life span and the price. A device known as Lux meter or illuminometer was used to measure the lumens given out by each lamp.

\section{Results and Discussion}

Results of the present study were presented below in detail

\section{Lighting requirements in gardens}

When designing or making changes in garden lighting, it is important to first understand the light requirements of the garden. Lighting requirements in gardens were presented in Table 1.

When existing/available solar lamps were evaluated, it was found that more or less all the lamps had similar features like having weather proof capacity, easy to install, highly durable, long lasting working hours etc.

However they were different from each other in terms of size, shape and pattern. Only few lamps had 360 degrees of display of light while some have upward or downward light.
When the specifications of the lamps were compared it was found that plastic and stainless steel were the commonly used materials for making the solar lamps.

The specifications required to be mentioned by the manufacturer for solar lamps are material used for the lamp, weight of the lamp, size, diameter, height, battery capacity, solar panel size and capacity.

However the many of the manufacturers have given only 70-75 per cent of the information. Unless the complete information given, consumer will not be able to take the right decision to choose the correct type of solar lamp.

The table 2 and 3 indicates that the features of all the solar garden lamps were different from each other but the majority of the lamps were found to use the same size of battery i.e. $1.2 \mathrm{~V}$ except the lamp namely Scross bright which has larger storage capacity.

The power output of each lamp also varied according to the size of the lamp. Similarly the lamp lumens emitted, working hours and price for all the lamps varied.

Crocon lamp found to work for more number of hours (11hrs) compared to other lamps. Quace brand has least operating hours i.e. 5 hrs. Cost of the lamp varied between Rs. 300 to Rs.400.

It can be concluded that different types of solar garden lamps available in the market were identified and their features, specifications and parameters were compared.

It would help the consumers to aware of advantages and disadvantages of solar garden lamps. It could make them in easy selection based on their purpose and preferences. 


\begin{tabular}{|c|c|c|c|}
\hline \multicolumn{4}{|c|}{ Table.1 Description of solar garden lamps } \\
\hline $\begin{array}{l}\text { Name of solar } \\
\text { garden lamps }\end{array}$ & Description & Salient features & Image \\
\hline $\begin{array}{c}\text { Scross Bright } \\
\text { waterproof solar } \\
\text { wireless } \\
\text { security motion } \\
\text { sensor LED } \\
\text { night light for } \\
\text { outdoor/garden } \\
\text { wall (Black) }\end{array}$ & $\begin{array}{l}\text { It has wireless motion sensor from } \\
\text { scross runs on solar energy (even on } \\
\text { weak sunlight) and comes with } 20 \\
\text { LED lights. It is suitable for outdoor } \\
\text { use and well suited to withstand all } \\
\text { seasons. }\end{array}$ & $\begin{array}{l}>\text { Weather resistance } \\
>\text { Easy to assemble } \\
>\text { Long lasting working } \\
\text { hours } \\
>\text { Easy to install } \\
>\text { Easy to move } \\
>\text { Highly durable } \\
>\text { Ability to detect motion } \\
\text { and illuminate the path } \\
\text { automatically }\end{array}$ & \\
\hline $\begin{array}{l}\text { Crocon new } \\
\text { solar powered } \\
\text { rechargeable } \\
\text { LED garden } \\
\text { light auto on/off } \\
\text { waterproof }\end{array}$ & $\begin{array}{l}\text { LED garden light in any open space } \\
\text { where direct sunlight falls on it during } \\
\text { the day. It will charge during the day, } \\
\text { and the sensor will automatically } \\
\text { activate the lights at night. }\end{array}$ & $\begin{array}{l}>\text { The LED light will light } \\
\text { up in multiple colours. } \\
>\text { No external battery or } \\
\text { power required. } \\
>\text { No wiring required. } \\
>\text { Easy to install } \\
>\text { Weather resistance } \\
>\text { Long lasting working } \\
\text { hours }\end{array}$ & \\
\hline $\begin{array}{l}\text { Quace solar } \\
\text { garden light }\end{array}$ & $\begin{array}{l}\text { It is meant for ambient lighting only, } \\
\text { does not solve the purpose of brightly } \\
\text { illuminating the garden. It can be } \\
\text { installed in the garden, flowerbed, and } \\
\text { greensward or anywhere in direct } \\
\text { sunlight during the day. }\end{array}$ & $\begin{array}{l}>\text { Eco friendly } \\
>\text { Energy saving } \\
>\text { Waterproof } \\
>\text { Rechargeable } \\
>\text { Automatic light } \\
\text { sensitive function } \\
>\text { No wiring required } \\
>\text { No need for extra } \\
\text { maintenance } \\
>\text { ABS land inserted } \\
\text { socket will never have } \\
\text { corrosion rust. }\end{array}$ & \\
\hline Ozoy solar light & $\begin{array}{l}\text { It is ideal for lighting front doors, } \\
\text { patios, decks, around the pool and } \\
\text { outdoor seating areas. Solar panel is } \\
\text { made of Polycrystalline silicon. }\end{array}$ & $\begin{array}{l}>\text { Highly water resistant } \\
\text { with 1P65 waterproof } \\
\text { level, making it great } \\
\text { during sun or rain. } \\
>\text { Auto light at night and } \\
\text { auto charge in the day } \\
\text { time without photo } \\
\text { resistance. } \\
>\text { Easy to install and use } \\
>\text { No wiring required } \\
>\text { Highly durable } \\
>\text { Weather resistance }\end{array}$ & \\
\hline
\end{tabular}




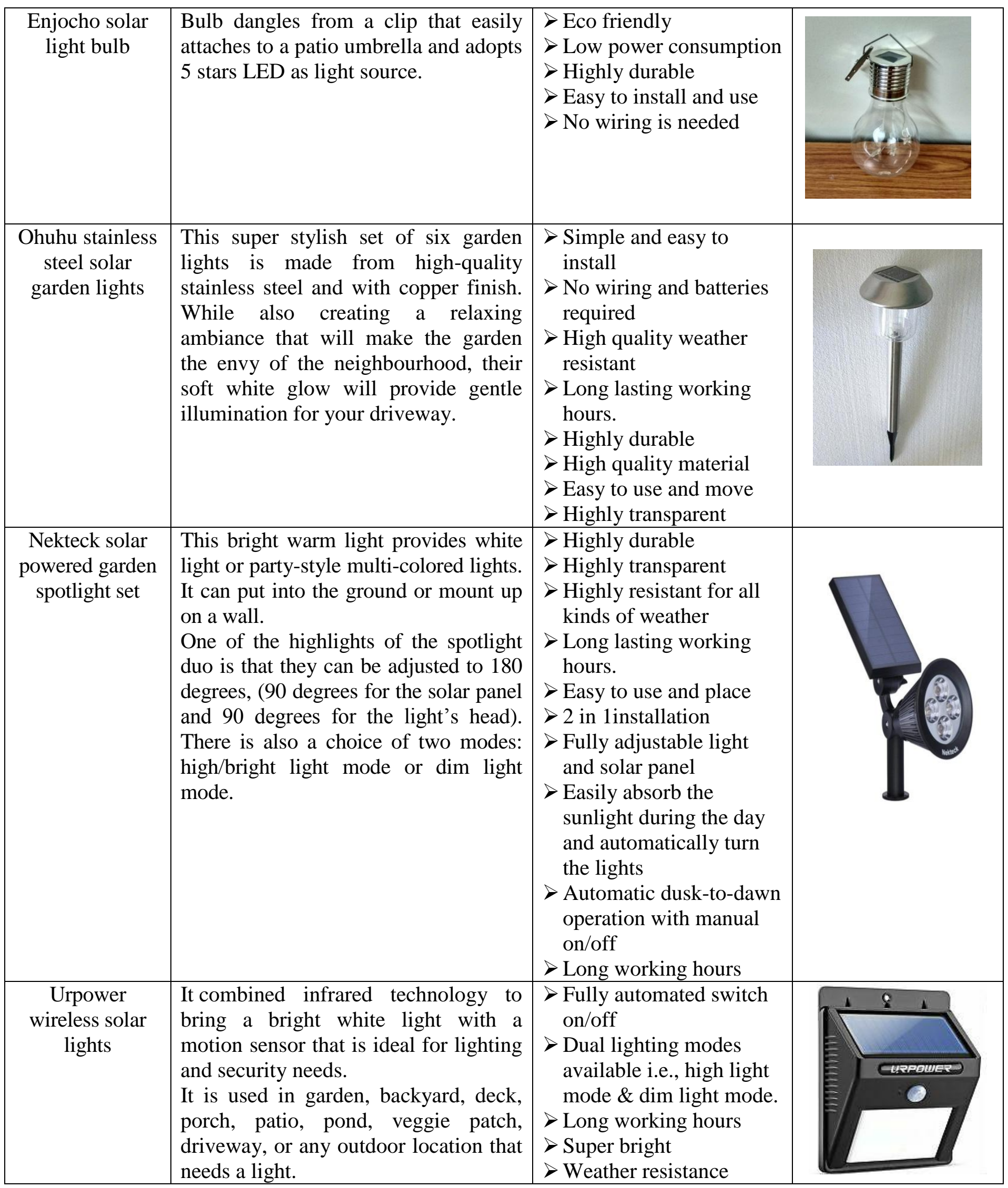




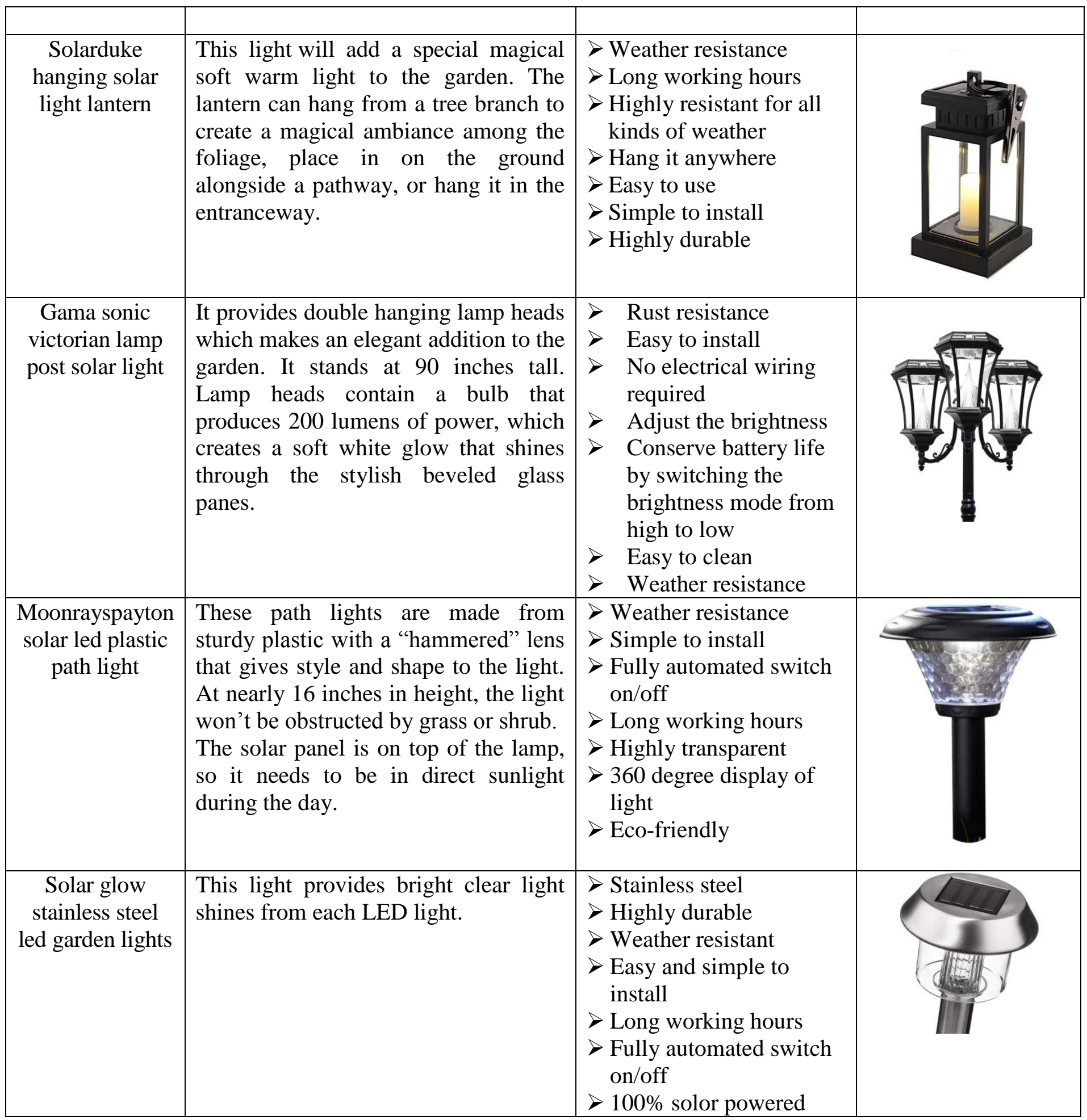




\begin{tabular}{|c|c|c|}
\hline $\begin{array}{c}\text { Newhouse } \\
\text { lighting solar } \\
\text { flickering LED } \\
\text { tiki torches }\end{array}$ & $\begin{array}{c}\text { This light consists of 3 internal LEDs } \\
\text { enclosed behind a frosted lens. Of the } \\
\text { 3 LEDs, one flickers creating the } \\
\text { romantic feel of a flickering flame. } \\
\text { With solar dusk-to-dawn functionality, } \\
\text { the torches recharge its internal NI-Cd } \\
\text { batteries during the day using the } \\
\text { required } \\
\text { sun's rays, and automatically } \\
\text { illuminate at night using its built-in } \\
\text { photo cell, making these the perfect } \\
\text { addition to poolside's, backyards, } \\
\text { patios or any outdoor environment }\end{array}$ & $>$ \\
\hline
\end{tabular}

\begin{tabular}{|c|c|c|c|c|c|c|c|c|}
\hline $\begin{array}{l}\text { S. } \\
\text { No }\end{array}$ & $\begin{array}{l}\text { Name of the } \\
\text { lamps }\end{array}$ & Weight & $\begin{array}{c}\text { Product } \\
\text { dimension }\end{array}$ & $\begin{array}{l}\text { Battery } \\
\text { capacity }\end{array}$ & Sensor & $\begin{array}{c}\text { Solar } \\
\text { panel } \\
\text { capacity }\end{array}$ & $\begin{array}{c}\text { Dimension } \\
\text { of solar } \\
\text { panel }\end{array}$ & Material \\
\hline 1. & $\begin{array}{c}\text { Scross Bright } \\
\text { waterproof } \\
\text { solar } \\
\text { wireless } \\
\text { security } \\
\text { motion } \\
\text { sensor LED } \\
\text { night light } \\
\text { for } \\
\text { outdoor/gard } \\
\text { en wall } \\
\text { (Black) }\end{array}$ & $198 \mathrm{gm}$ & $\begin{array}{c}95 \times 124 \times \\
48 \mathrm{~mm}\end{array}$ & $\begin{array}{l}3.7 \mathrm{v} \\
\text { lithium } \\
\text { ion }\end{array}$ & $\begin{array}{l}\text { Automa } \\
\text { tic } \\
\text { sensor }\end{array}$ & $0.55 \mathrm{kw}$ & - & Plastic \\
\hline 2. & $\begin{array}{l}\text { Crocon new } \\
\text { solar } \\
\text { powered } \\
\text { rechargeable } \\
\text { LED garden } \\
\text { light auto } \\
\text { on/off } \\
\text { waterproof }\end{array}$ & $90 \mathrm{gm}$ & $5.5 \times 38 \mathrm{~cm}$ & $\begin{array}{c}1.2 \mathrm{~V} / 600 \\
\mathrm{mAh} \mathrm{Ni}- \\
\mathrm{Cd}\end{array}$ & $\begin{array}{l}\text { Automa } \\
\text { tic } \\
\text { sensor }\end{array}$ & $0.18 \mathrm{~W}$ & $3 \times 4 \mathrm{~cm}$ & $\begin{array}{l}\text { Stainless } \\
\text { steel and } \\
\text { plastic }\end{array}$ \\
\hline 3. & $\begin{array}{l}\text { Enjocho } \\
\text { solar light } \\
\text { bulb }\end{array}$ & - & $15 \times 7.5 \mathrm{~cm}$ & 40MAH & - & $\begin{array}{c}1.2 \mathrm{~V} / 0.6 \\
\mathrm{~W}\end{array}$ & $2 \times 4 \mathrm{~cm}$ & $\begin{array}{l}\text { polypropy } \\
\text { lene }\end{array}$ \\
\hline 4. & $\begin{array}{l}\text { Quace solar } \\
\text { garden light }\end{array}$ & $90.7 \mathrm{gm}$ & $\begin{array}{c}5.5 \times 5.5 \mathrm{x} \\
38 \mathrm{~cm}\end{array}$ & $\begin{array}{c}1.2 \mathrm{~V} / 600 \\
\mathrm{mAh} \mathrm{AA} \\
\mathrm{Ni}-\mathrm{Cd}\end{array}$ & - & $\begin{array}{l}2 \mathrm{~V} / 50 \mathrm{~m} \\
\mathrm{~A}(0.1 \mathrm{~W})\end{array}$ & - & $\begin{array}{l}\text { Plastic, } \\
\text { stainless } \\
\text { steel }\end{array}$ \\
\hline
\end{tabular}




\begin{tabular}{|c|c|c|c|c|c|c|c|c|}
\hline 5. & $\begin{array}{c}\text { Ozoy solar } \\
\text { light }\end{array}$ & - & $\begin{array}{c}9 \mathrm{x} 5 \mathrm{x} \\
13 \mathrm{~cm}\end{array}$ & $\begin{array}{c}1.2 \mathrm{~V} / 1200 \\
\mathrm{mAh} \text { AA } \\
\mathrm{Ni}-\mathrm{MH}\end{array}$ & - & $\begin{array}{c}2 \mathrm{~V} / 120 \mathrm{~m} \\
\mathrm{~A}(0.24 \\
\mathrm{W})\end{array}$ & - & - \\
\hline 6. & $\begin{array}{c}\text { Ohuhu } \\
\text { stainless } \\
\text { steel solar } \\
\text { garden lights }\end{array}$ & - & $\begin{array}{c}29 \times 9.5 \times \\
34 \mathrm{~cm}\end{array}$ & $\begin{array}{c}600 \mathrm{MA} / 2 \\
\mathrm{~V}\end{array}$ & - & $\begin{array}{c}2 \mathrm{~V} / \\
60 \mathrm{Ma}\end{array}$ & - & $\begin{array}{c}\text { Glass, } \\
\text { stainless } \\
\text { steel poli- } \\
\text { silicon }\end{array}$ \\
\hline 7. & $\begin{array}{l}\text { Nekteck solar } \\
\text { powered } \\
\text { garden } \\
\text { spotlight set }\end{array}$ & $794 \mathrm{~g}$ & $3.74 "$ & $\begin{array}{c}3.7 \mathrm{~V} \\
2200 \mathrm{mAh}\end{array}$ & - & - & $3.42 ” \times 5.66 ”$ & Plastic \\
\hline 8. & $\begin{array}{l}\text { Urpower } \\
\text { wireless solar } \\
\text { lights }\end{array}$ & $635 \mathrm{~g}$ & $\begin{array}{c}13.2 \times 9.2 \\
\times 7.7 \mathrm{~cm}\end{array}$ & $\begin{array}{c}3.7 \mathrm{~V} 900 \mathrm{~m} \\
\mathrm{Ah}\end{array}$ & - & - & - & Plastic \\
\hline 9. & $\begin{array}{l}\text { Solarduke } \\
\text { hanging solar } \\
\text { light lantern }\end{array}$ & - & $4 " x$ 4"x 8" & $\begin{array}{c}1.2 \mathrm{~V} \\
/ 1200 \mathrm{mAh} \\
\text { AA Ni- } \\
\text { MH }\end{array}$ & - & $\begin{array}{c}2.7 \mathrm{~V} 0.1 \\
\mathrm{~W}\end{array}$ & - & Metal \\
\hline 10. & $\begin{array}{l}\text { Gama sonic } \\
\text { victorian } \\
\text { lamp post } \\
\text { solar light }\end{array}$ & $4.5 \mathrm{kgs}$ & $\begin{array}{l}9 " \times 25 " \\
\text { x90" }\end{array}$ & $\begin{array}{l}3.2 \mathrm{~V} / 3000 \\
\text { mAh Li- } \\
\text { ion }\end{array}$ & - & - & - & $\begin{array}{l}\text { Aluminu } \\
\mathrm{m}\end{array}$ \\
\hline 11. & $\begin{array}{c}\text { Moonrayspay } \\
\text { ton solar led } \\
\text { plastic path } \\
\text { light }\end{array}$ & $1.3 \mathrm{kgs}$ & $\begin{array}{c}15.9 " \times 4.7 " \\
\text { x4.7" }\end{array}$ & $\begin{array}{c}\text { 400mAh } \\
\text { Ni-cd }\end{array}$ & - & $1.2 \mathrm{~V}$ & - & Plastic \\
\hline 12. & $\begin{array}{l}\text { Solarglow } \\
\text { stainless steel } \\
\text { led garden } \\
\text { lights }\end{array}$ & - & $\begin{array}{c}15 " \times 10.8 \\
\times 4.9\end{array}$ & $0.01 \mathrm{~V}$ & - & $3 \mathrm{~W}$ & $\begin{array}{c}10 \times 25 \times \\
101\end{array}$ & $\begin{array}{c}\text { Stainless } \\
\text { steel }\end{array}$ \\
\hline 13. & $\begin{array}{l}\text { Newhouse } \\
\text { lighting solar } \\
\text { flickering } \\
\text { LED tiki } \\
\text { torches }\end{array}$ & $0.45 \mathrm{~kg}$ & $\begin{array}{l}60 " x 4 " \\
\text { x60" }\end{array}$ & $\begin{array}{c}400 \mathrm{mAh} \\
\mathrm{Ni}-\mathrm{cd}\end{array}$ & - & - & - & Plastic \\
\hline
\end{tabular}

Table.3 Features, parameters identified and price of the solar garden lamps

\begin{tabular}{|c|c|c|c|c|c|c|c|c|}
\hline $\begin{array}{c}\text { S. } \\
\text { No }\end{array}$ & Types of solar lamps & \multicolumn{3}{|c|}{ Features } & \multicolumn{3}{c|}{ Parameters } & $\begin{array}{c}\text { Price } \\
\text { (Rs) }\end{array}$ \\
\cline { 2 - 8 } & & $\begin{array}{c}\text { Solar } \\
\text { panel } \\
\text { (W) }\end{array}$ & Battery(V) & Size (cm) & $\begin{array}{c}\text { Lumens } \\
\text { emitted }\end{array}$ & $\begin{array}{c}\text { Charging } \\
\text { hours }\end{array}$ & $\begin{array}{c}\text { Working } \\
\text { hours }\end{array}$ \\
\hline $\mathbf{1}$ & $\begin{array}{l}\text { Scross Bright waterproof } \\
\text { solar wireless security }\end{array}$ & 0.55 & 3.7 & $48 \times 95 \times 124$ & 600 & 8 & 8 & 332 \\
\hline
\end{tabular}




\begin{tabular}{|c|c|c|c|c|c|c|c|c|}
\hline & $\begin{array}{l}\text { motion sensor LED night } \\
\text { light for outdoor/garden } \\
\text { wall (Black) }\end{array}$ & & & & & & & \\
\hline 2 & $\begin{array}{l}\text { Crocon new solar } \\
\text { powered rechargeable } \\
\text { LED garden light auto } \\
\text { on/off waterproof }\end{array}$ & 0.18 & 1.2 & $5.5 \times 38$ & 90 & 8 & 11 & 319 \\
\hline 3 & Enjocho solar light bulb & 0.6 & 1.2 & $7.5 \times 15$ & 30 & 8 & 6 & 305 \\
\hline 4 & Quace solar garden light & 0.1 & 1.2 & $8 \times 30$ & 180 & 8 & 5 & 299 \\
\hline 5 & Ozoy solar light & 0.24 & 1.2 & $5 \times 9 \times 13$ & 100 & 8 & 9 & 399 \\
\hline
\end{tabular}

\section{References}

Ranjan, P., Kumar, S., Kumar, S and Naregalkar, P.R. 2016. Smart solar emergency lamp with motion detector. International Research Journal of Engineering and Technology. 3: 22462252.
Vinutharani, A and Vanamala, K.C. 2016. Sensor based smart lighting: A survey. International Research Journal of Engineering and Technology(IRJET). 2328-2330.

https://www.cn-solargardenlights.com/thecomposition-and-principle-of-solargarden-lights.html

\section{How to cite this article:}

Roshita Devi, M., Velivelli Vijaya Lakshmi, D. Ratna Kumari and Kameswari, S.L. 2019. Evaluation of Different Types of Solar Garden Lamps. Int.J.Curr.Microbiol.App.Sci. 8(11): 2564-2572. doi: https://doi.org/10.20546/ijcmas.2019.811.296 